\title{
Impact of routine histopathological examination of appendectomy specimens on patient management: a study of $\mathbf{4 0 1 2}$ appendectomy specimens
}

\author{
Osama Elfaedy ${ }^{1}$, Mohamed Benkhadoura ${ }^{2}$, Akrem Elshaikhy $^{3}$, Khaled Elgazwi ${ }^{3}$ \\ 1 Department of General Surgery, St. Luke's Hospital, Kilkenny, Ireland \\ ${ }^{2}$ Department of General Surgery, Benghazi Medical Center, Benghazi University, Benghazi, Libya \\ ${ }^{3}$ Department of General Surgery, Al-jala Hospital, Benghazi University, Benghazi, Libya
}

\begin{abstract}
Objective: For a suspected diagnosis of acute appendicitis, appendectomy is one of the most common emergency abdominal operations performed. However, the need for routine histopathological examination (HPE) of all appendectomy specimens has recently been questioned. The aim of this study was to assess whether a routine HPE of appendectomy specimens is needed and whether routine HPE has an impact on further management of patients.
\end{abstract}

Material and Methods: From January 2009 to June 2017, all histopathology reports of 4012 consecutive appendectomy specimens for a clinical suspicion of acute appendicitis were retrospectively analyzed in two university hospitals.

Results: Out of the 4012 cases, 3530 (88\%) patients showed findings consistent with acute appendicitis on HPE. Perforation rate was 5.8\% and was significantly higher in male patients $(p<0.001)$ and higher in the $>30$ years age group $(p=0.024)$. Negative appendectomy rate was $5.6 \%$ and was significantly higher in female patients $(p<0.001)$. There were $256(6.4 \%)$ patients who demonstrated unusual findings in their HPE, which included chronic appendicitis ( $n=207 ; 5.2 \%)$ patients, Enterobius vermicularis $(n=14)$, Schistosoma $(n=8)$, Crohn's disease $(n=1)$, neuroma $(n=10)$, carcinoid tumour $(n=5)$ and mucinous cystadenoma $(n=5)$, mucocele $(n=4)$ and mucinous cystadenocarcinoma $(n=2)$.

Conclusion: HPE of the appendix does not only confirm the diagnosis of acute appendicitis, but also detects other unusual diagnoses that may have an impact on a patient's management. A number of patients with unusual histopathological findings require anti-helmentic treatment, colectomy, gastroenterology follow-up or periodic surveillance. Hence, all appendectomy specimens must be submitted for routine HPE.

Keywords: Appendectomy, appendicitis, histopathological examination

Cite this article as: Elfaedy O, Benkhadoura M, Elshaikhy A, Elgazwi K. Impact of routine histopathological examination of appendectomy specimens on patient management: a study of 4012 appendectomy specimens. Turk J Surg 2019; 35 (3): 196-201.

Corresponding Author

Mohamed Benkhadoura

E-mail:khdoura@yahoo.com

Received: 21.06 .2018

Accepted: 14.09 .2018

Available Online Date: 23.09.2019

O Copyright 2019 by Turkish Surgical Society Available online at www.turkjsurg.com

DOI: $10.5578 /$ turkjsurg.4253

\section{INTRODUCTION}

Acute appendicitis is the most common abdominal emergencies encountered in general surgical services. The overall lifetime risk of acute appendicitis is about $7.0 \%$, with $8.6 \%$ for males and $6.7 \%$ for females (1). Diagnosis of acute appendicitis is a major challenge, even for experienced surgeons since typical presentations only appear in about $60 \%$ of the patients (2). In addition, many conditions mimic acute appendicitis in their presentation especially in women, causing diagnostic difficulties and increasing the rate of negative appendectomies (3). Thus, histopathological examination (HPE) is still considered the most accurate method for confirming appendicitis diagnosis.

There has been a debate in the literature concerning the routine or selective HPE of appendectomy specimens (3). However, a policy of selective HPE may miss significant pathology, which may have an impact on patient management. Furthermore, HPE of appendectomy specimens may detect other unusual findings such as parasitic infections, endometriosis or granulomatosis (4).

The aim of this study was to assess whether a routine HPE of appendectomy specimens is needed and whether routine HPE has an impact on further management of patients.

\section{MATERIAL and METHODS}

From January 2009 to June 2017, all histopathology reports of 4012 consecutive appendectomy specimens for a clinical suspicion of acute appendicitis were retro- 
spectively analyzed in two university hospitals. The research was performed according to the World Medical Association Declaration of Helsinki.

Patient details such as age, sex, and histopathological diagnosis were recorded. Exclusion criteria were appendectomies performed in conjunction with bowel resections or other pelvic surgeries and paediatric ages $<13$ years. Appendectomy performed for a suspicion of acute appendicitis where HPE showed normal appendix was considered negative appendectomy.

\section{Statistical Analysis}

All statistical analyses were performed using the Statistical Package for the Social Sciences (SPSS Inc.; Chicago, IL, USA), version 18.0 software program. The data was analyzed using the Chisquare test. A p value $<0.05$ was considered to indicate statistical significance.

\section{RESULTS}

Of the 4012 appendectomy specimens were sent for HPE during the study period, 1846 (46\%) were males and 2166 (54\%) were females, with a median age of 23 (range, 13-91) years. The most common age group for appendectomy in this study was 1320 years (39.9\%) closely followed by the 21-30 year age group (37.2\%), together constituting $77.1 \%$ of total specimens. The distribution of histopathological diagnosis is shown in Table 1.

Out of the 4012 cases, 3530 (88\%) patients showed findings consistent with acute appendicitis on HPE that includes early acute appendicitis, acute suppurative appendicitis, gangrenous appendicitis and perforated appendicitis. The histopathological finding of acute appendicitis was highest in the second decade of life, followed by those in their third and fourth decades of life, at $88.8 \%$, $88.0 \%$, and $87.2 \%$, respectively. About $77.4 \%$ of acute appendicitis cases were found in the age group of 13 to 30 years (Table 2).
Table 1. Histopathological diagnoses encountered in the appendectomy specimens

\begin{tabular}{|l|c|c|}
\hline Diagnosis & Number & Percentage \\
\hline Early acute appendicitis & 526 & 13.1 \\
\hline Acute suppurative appendicitis & 2774 & 69.1 \\
\hline Gangrenous appendicits & 26 & 0.6 \\
\hline Perforated appendicits & 204 & 5.1 \\
\hline Chronic appendicits & 207 & 5.2 \\
\hline Normal appendix & 226 & 5.6 \\
\hline Crohn's disease & 1 & 0.02 \\
\hline Schistosoma infection & 8 & 0.2 \\
\hline Enterobius vermicularis & 14 & 0.3 \\
\hline Carcinoid & 5 & 0.1 \\
\hline Cystadenocarcinoma & 2 & 0.04 \\
\hline Cystadenoma & 5 & 0.1 \\
\hline Mucocele & 4 & 0.1 \\
\hline Neuroma & 10 & 0.2 \\
\hline Total & 4012 & 100 \\
\hline & & \\
\hline
\end{tabular}

In the 3530 patients with acute appendicitis, there were 204 patients with perforated appendicitis with an overall perforation rate of 5.8\%. Male patients had a significantly higher perforation rate than female patients ( $n=148 ; 8.8 \%$ vs. $n=56 ; 3.0 \% ; p<0.001$ ). The age group of $>30$ years had a higher perforation rate than that of the age group of $\leq 30$ years $(7.4 \%$ vs. $5.3 \% ; p=0.024)$. The perforation rate gradually increased with patient age from the second decade (4.7\%) till the seventh decade (11.1\%) and then decreased to zero in patients older than 70 years of age (Table 3 ).

Table 2. Distribution of the incidence of acute appendicitis, normal appendix, and unusual finding according to patient age

\begin{tabular}{|c|c|c|c|c|c|c|c|}
\hline \multirow[b]{2}{*}{ Age group } & \multirow[b]{2}{*}{$\begin{array}{c}\text { Proportion } \\
\text { of patients } \\
\text { (\%) }\end{array}$} & \multicolumn{2}{|c|}{$\begin{array}{l}\text { Acute appendicitis } \\
\qquad(n=3530)\end{array}$} & \multicolumn{2}{|c|}{$\begin{array}{l}\text { Normal appendix } \\
\qquad(n=226)\end{array}$} & \multicolumn{2}{|c|}{$\begin{array}{l}\text { Unusual findings } \\
\qquad(n=256)\end{array}$} \\
\hline & & $\begin{array}{c}\text { (\%) within } \\
\text { the age } \\
\text { group }\end{array}$ & $\begin{array}{l}\text { (\%) within } \\
\text { the } \\
\text { diagnosis }\end{array}$ & $\begin{array}{c}\text { (\%) within } \\
\text { the age } \\
\text { group }\end{array}$ & $\begin{array}{l}\text { (\%) within } \\
\text { the } \\
\text { diagnosis }\end{array}$ & $\begin{array}{c}\text { (\%) within } \\
\text { the age } \\
\text { group }\end{array}$ & $\begin{array}{c}\text { (\%) within } \\
\text { the } \\
\text { diagnosis }\end{array}$ \\
\hline $13-20$ & 39.9 & 88.8 & 40.2 & 5.9 & 41.6 & 5.3 & 33.2 \\
\hline $21-30$ & 37.2 & 88 & 37.2 & 5.8 & 38.5 & 6.2 & 36.3 \\
\hline $31-40$ & 15 & 87.2 & 14.8 & 4.7 & 12.4 & 8.2 & 19.1 \\
\hline $41-50$ & 4.8 & 86.5 & 4.7 & 6.7 & 5.8 & 6.7 & 5.1 \\
\hline $51-60$ & 1.8 & 86.1 & 1.8 & 4.2 & 1.3 & 9.7 & 2.7 \\
\hline $61-70$ & 0.8 & 84.4 & 0.8 & 3.1 & 0.4 & 12.5 & 1.6 \\
\hline $71-80$ & 0.3 & 69.2 & 0.3 & 0 & 0.0 & 30.8 & 1.6 \\
\hline $81-91$ & 0.2 & 85.7 & 0.2 & 0 & 0.0 & 14.3 & 0.4 \\
\hline
\end{tabular}


Table 3. Distribution of the incidence of acute appendicitis and perforation rate with patient age

\begin{tabular}{|l|c|c|c|}
\hline \multirow{2}{*}{ Age group } & $\begin{array}{c}\text { Proportion } \\
\text { of acute appendicitis (\%) } \\
(\mathbf{n = 3 5 3 0 )}\end{array}$ & $\begin{array}{c}\text { (\%) within } \\
\text { the age } \\
\text { group }\end{array}$ & $\begin{array}{c}\text { (\%) within } \\
\text { the } \\
\text { diagnosis }\end{array}$ \\
\hline $13-20$ & 40.2 & 4.7 & 32.8 \\
\hline $21-30$ & 37.2 & 5.9 & 38.2 \\
\hline $31-40$ & 14.8 & 6.9 & 17.6 \\
\hline $41-50$ & 4.7 & 8.4 & 6.9 \\
\hline $51-60$ & 1.8 & 9.7 & 2.9 \\
\hline $61-70$ & 0.8 & 11.1 & 1.5 \\
\hline $71-80$ & 0.3 & 0.0 & 0.0 \\
\hline $81-91$ & 0.2 & 0.0 & 0.0 \\
\hline & & & \\
\hline
\end{tabular}

The HPE of the appendix was normal in 226 (5.6\%) of the 4012 patients who were operated on with a clinical suspicion of acute appendicitis. Negative appendectomy rate (NAR) was significantly higher in female $(n=161 ; 7.4 \%)$ than in male $(n=65 ; 3.5 \%)$ patients $(p<0.001)$. However, there was no significant statistical difference in the NAR when the $\leq 30$ year age group compared to $>30$ year age groups ( $5.9 \%$ vs. $4.9 \% ; p=0.274$ ).

Of the 4012 patients who had appendectomy for preoperative suspicion of acute appendicitis, 256 (6.4\%) had unusual findings in their HPE. There were 103 (5.6\%) males and 153 (7.1\%) females $(p=0.055)$. Median age was 25 (range, 13-81) years. Unusual histopathological finding was highest in the seventh, eighth and ninth decades of life, at $12.5 \%, 30.8 \%$, and $14.3 \%$, respectively. About $69.5 \%$ of unusual finding cases were found in the age group of 13 to 30 years (Table 2). The rate of unusual finding was higher in the $>30$ year age group compared to $\leq 30$ year age group (8.5\% vs. 5.8\%; $p=0.003)$.

The most common unusual finding in the HPE of appendectomy specimens was chronic appendicitis seen in 207 (5.2\%) patients. Parasitic infections were discovered in 22 patients, of these 14 were Enterobius vermicularis and eight were Schistosoma. Crohn's disease was reported in one case.

Of the $26(0.6 \%)$ appendiceal tumours, the most common appendiceal tumour was neuroma, found in 10 patients, followed by carcinoid tumour $(n=5)$ and mucinous cystadenoma $(n=5)$. Mucocele was found in four and mucinous cystadenocarcinoma in two; one of them complicated by pseudomyxoma peritonei.

\section{DISCUSSION}

For a clinical diagnosis of acute appendicitis, appendectomy is one of the most common emergency abdominal operations performed (5).
In this study, 88\% of the appendectomy specimens had histological evidence of acute appendicitis, comparable with other studies (65-91\%) (4). The incidence of acute appendicitis in our study was higher in the second and third decade, about $76.4 \%$ of acute appendicitis occurring below 30 years of age, similar to other studies $(6,7)$.

While other studies $(2,7,8)$ have shown male predominance, our study showed slightly female predominance with a female to male ratio of 1.1:1, consistent with the study of Shreshtha et al. (9).

In our study, the perforation rate of $5.8 \%$ and was comparable to that reported by Charfi et al. (10) (6.4\%) and Chandrasegaram et al. (8) (7.4\%). However, several studies $(1,2,7,11)$ have reported much higher rates of $11-22.5 \%$. By contrast, Shrestha et al. (9) and Jat et al. (12) have found a low rate of $1.9 \%$ and $2 \%$, respectively. Most studies have demonstrated that the incidence of appendicular perforation increases with age $(2,7,8)$, which is consistent with the present study.

NAR in the present study was 5.6\%. In 2011, Swank et al. (4) reviewed the literature and found that NAR was between 8 and $32 \%$ in 55 and 138 appendectomies, respectively (4). Recently, Emre et al. (1) have reported a NAR of $6 \%$ and Jat et al. (12) have reported a rate of $3 \%$. van Rossem et al., (11) hav reported a NAR of $2.2 \%$. It has been shown that routine diagnostic imaging (US or $\mathrm{CT}$ ) lowers NAR in patients with suspected appendicitis to 1.7$6.2 \%$ (13), which was consistent with our findings.

NAR in the present study was significantly higher in female patients, consistent with other studies $(2,7-9)$. This is likely due to the difficulties in diagnosing acute appendicitis in female patients because of the added possibility of gynaecological conditions that mimic acute appendicitis (8).

Although acute appendicitis is the most common histopathological finding affecting the appendix, chronic appendicitis was the most common unusual finding on HPE of the appendectomy specimens in the current study. Chronic appendicitis does not present with typical symptoms of acute appendicitis and diagnosis is frequently made following an appendectomy and based on HPE (14). In our study, the rate of chronic appendicitis was $5.2 \%$. Shreshtha et al. and Dincel et a. havel reported lower rates of $2.6 \%$ and $0.2 \%$, respectively $(9,14)$. In a study conducted by Rehman et al., $7.9 \%$ of a total of 316 patients has been found to have chronic appendicitis (15).

E. vermicularis is the most prevalent parasitic infection of the gastrointestinal tract. The incidence of E. vermicularis ranges from 0.6\% to $3.8 \%$ in all appendectomy specimens; however, the rates of inflammation in appendices infested with these parasites is $13 \%$ to $37 \%$ (16). Appendectomy only treats the consequences but not the cause of the disease. For this reason, these patients should also receive anthelmintic treatment (oral mebendazole) (14). In the present study, fourteen patients (0.3\%) had E. ver- 
micularis in their specimens, with the incidence being slightly lower than that of other published studies.

Schistosomiasis is another uncommon cause of appendicitis. Patients with Schistosomal appendicitis should be treated with praziquantel after surgery (14). The incidence of Schistosomal appendicitis was reported to be $0.1 \%$ by Dincel et al. (14) and $2.3 \%$ by Gali et al. (17). In the current study, $8(0.2 \%)$ cases had Schistosomiasis.

Crohn's disease of the appendix is usually associated with Crohn's disease of the ileum and caecum. Isolated Crohn's disease of the appendix is rare and often mimics acute appendicitis in clinical presentation. Crohn's disease has been found to be the cause of acute appendicitis in $0.2 \%$ to $1.8 \%$ of all appendectomies. Appendectomy is considered adequate if the disease is restricted to the appendix. However, patients with ileocaecal involvement may need further ileocaecal resection. Patients with Crohn's disease need further gastroenterology follow-up postoperatively (18). In the present study, only one patient had Crohn's disease in their appendectomy specimen.

Appendiceal tumours, found in less than 3\% of all appendectomies, are usually asymptomatic and are usually identified either intraoperatively or during the HPE (19). Carcinoid tumour of the appendix is the most common type of primary malignant tumour of the appendix. It represents $60 \%$ of all appendiceal tumours and is discovered in $0.3 \%$ to $2.3 \%$ of the appendectomy specimens $(1,14)$. In the current study, we had slightly lower incidence of appendiceal carcinoids (0.1\%) compared to other studies. Carcinoids are rarely diagnosed preoperatively, and they are commonly identified as an incidental finding during appendectomy. They are mostly benign, $<1 \mathrm{~cm}$ in size, and rarely metastasize. For carcinoids $<1 \mathrm{~cm}$ in size, the risk of metastasis is exceedingly low and simple appendectomy is considered curative. However, with carcinoids $\geq 2 \mathrm{~cm}$, the risk of metastasis increases up to $85 \%$ and patients usually proceed to right hemicolectomy $(1,14,16,17,19)$.

Mucocele of the appendix is a rare disease characterized by a distended, mucus-filled appendix. Retention cyst, mucosal hyperplasia, mucinous cystadenoma, and mucinous cystadenocarcinoma are the histological types of mucocele of the appendix. It is found in $0.2 \%$ to $0.7 \%$ of all appendectomy specimens $(14,20,21)$. Mucoceles are frequently discovered incidentally during appendectomy (19). Mucinous cystadenoma is treated by simple appendectomy whereas a cystadenocarcinoma should undergo a right hemicolectomy. During the follow-up period, patients should undergo radiological (US \& $\mathrm{CT}$ ) and colonoscopic investigations since mucinous cystadenoma is strongly associated with colonic and ovarian malignancy $(14,16,19)$. In this study, eleven $(0.27 \%)$ patients had mucocele in their appendectomy specimens and this incidence was comparable with other studies.
Appendiceal neuromas (fibrous obliteration of the appendix) are rare and characterized by fibrous obliteration on HPE of the appendix. The majority of appendiceal neuromas are often incidentally discovered (22). The incidence of appendiceal neuromas in our study was only $0.2 \%$, which is lower than that reported by Yilmaz et al. (21) (3.7\%) and Emre et al. (1) (4.5\%).

\section{CONCLUSION}

HPE of the appendix does not only confirm the diagnosis of acute appendicitis but also detects other pathological lesions that may not be obvious intraoperatively, and furthermore, routine HPE has a direct impact on patient management such as anti-helmentic treatment, further resection, endoscopic and gastroenterology follow-up or periodic surveillance. Hence, we conclude that all appendectomy specimens must be submitted for routine HPE regardless of the gross appearance of the specimen at operation.

\section{ACKNOWLEDGEMENT}

The authors would like to thank Essam S. Hussein, head of data management at Benghazi medical centre, for help with statistical analysis.

Ethics Committee Approval: Authors declared that the research was conducted according to the principles of the World Medical Association Declaration of Helsinki "Ethical Principles for Medical Research Involving Human Subjects", (amended in October 2013).

Informed Consent: Due to the retrospective design of the study, the informed consent was not obtained.

Peer-review: Externally peer-reviewed.

Author Contributions: Consept - O.E., M.B.; Design - O.E., A.E., K.E.; Supervision - O.E., K.E.; Resource - O.E., M.B., K.E.; Materials - M.B., A.E.; Data Collection and/or Processing - M.B., A.E.; Analysis and Interpretation - O.E., M.B., K.E.; Literature Search - O.E., K.E.; Writing Manuscript - O.E., M.B., K.E.; Critical Reviews - All of authors.

Conflict of Interest: No conflict of interest was declared by the authors.

Financial Disclosure: The authors declared that this study has received no financial support.

\section{REFERENCES}

1. Emre A, Akbulut S, Bozdag Z, Yilmaz M, Kanlioz M, Emre R, et al. Routine histopathologic examination of appendectomy specimens: retrospective analysis of 1255 patients. Int Surg 2013; 98: 354-62. [CrossRef]

2. Ma KW, Chia NH, Yeung HW, Cheung MT. If not appendicitis, then what else can it be? A retrospective review of 1492 cases of appendicitis. Hong Kong Med J 2010; 16: 12-7.

3. Omiyale AO, Adjepong S. Histopathological correlations of appendectomies: a clinical audit of a single center. Ann Trans/ Med 2015; 3: 119.

4. Swank HA, Eshuis EJ, Ubbink DT, Bemelman WA. Is routine histopathological examination of appendectomy specimens useful? A systematic review of the literature. Colorectal Dis 2011; 13:1214-21. [CrossRef] 
5. Martellucci J, Fontani A, Tanzini G. Is routine pathological examination necessary in appendectomy for acute appendicitis? Int J Colorectal Dis 2009; 24: 1243. [CrossRef]

6. Oguntola AS, Adeoti ML, Oyemolade TA. Appendicitis: Trends in incidence, age, sex, and seasonal variations in South-Western Nigeria. Ann Afr Med 2010; 9: 213-7. [CrossRef]

7. Marudanayagam R, Williams GT, Rees BI. Review of the pathological results of 2660 appendicectomy specimens. J Gastroenterol 2006; 41 : 745-9. [CrossRef]

8. Chandrasegaram MD, Rothwell LA, An El, Miller RJ. Pathologies of the appendix: a 10-year review of 4670 appendicectomy specimens. ANZ J Surg 2012; 82: 844-7. [CrossRef]

9. Shreshtha R, Ranabhat SR, Tiwari M. Histopathological analysis of appendectomy specimens. J Pathol Nepal 2012; 2: 215-9. [CrossRef]

10. Charfi S, Sellami A, Affes A, Yaïch K, Mzali R, Boudawaraet TS. Histopathological findings in appendectomy specimens: a study of 24,697 cases. Int J Colorectal Dis 2014; 29: 1009-12. [CrossRef]

11. van Rossem CC, Bolmers MD, Schreinemacher MH, van Geloven AA, Bemelman WA. Prospective nationwide outcome audit of surgery for suspected acute appendicitis. Br J Surg 2015; 103: 144-51. [CrossRef]

12. Jat MA, Al-Swailmi FK, Mehmood Y, Alrowaili M, Alanazi S. Histopathological examination of appendicectomy specimens at a district hospital of Saudi Arabia. Pak J Med Sci 2015; 31: 891-4.

13. de Burlet KJ, Crane G, Cullinane R, Larsen PD, Dennett ER. Review of appendicectomies over a decade in a tertiary hospital in New Zealand. ANZ J Surg 2018; 88: 1253-7. [CrossRef]

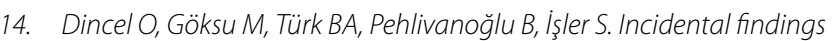
in routine histopathological examination of appendectomy specimens; retrospective analysis of 1970 patients. Indian J Surg 2018; 80: 48-53. [CrossRef]
15. Rehman S, Khan Al, Ansari HA, Alam F, Vasenwala SM, Alam K, et al. Retrospective analysis of appendicectomy specimens: A tertiary care center-based study. Saudi Surg J 2017; 5: 71-5. [CrossRef]

16. Yabanoglu H, Caliskan K, Ozgur Aytac H, Turk E, Karagulle E, Kayaselcuk F, et al. Unusual findings in appendectomy specimens of adults: retrospective analyses of 1466 patients and a review of literature. Iran Red Crescent Med J 2014; 16:e12931. [CrossRef]

17. Gali BM, Nggada HA. Schistosomiasis of the appendix in Maiduguri. Trop Doctor 2006; 36: 162-3. [CrossRef]

18. Machado NO, Chopra PJ, Hamdani AA. Crohn's disease of the appendix with enterocutaneous fistula post-appendicectomy: An approach to management. NAm J Med Sci. 2010 Mar; 2: 158-61.

19. Akbulut S, Tas M, Sogutcu S, Arikanoglu Z, Basbug M, Ulku A, et al. Unusual histopathological findings in appendectomy specimens: A retrospective analysis and literature review. World I Gastroenterol 2011; 17: 1961-70. [CrossRef]

20. Demetrashvili Z, Chkhaidze M, Khutsishvili K, Topchishvili G, Javakhishvili T, Pipia I, et al. Mucocele of the appendix: case report and review of literature. Int Surg 2012; 97: 266-9. [CrossRef]

21. Yilmaz M, Akbulut S, Kutluturk K, Sahin N, Arabaci E, Ara C, et al. Unusual histopathological findings in appendectomy specimens from patients with suspected acute appendicitis. World J Gastroenterol 2013; 19: 4015-22. [CrossRef]

22. Patel AV, Friedman M, MacDermott RP. Crohn's disease patient with right lower quadrant abdominal pain for 20 years due to an appendiceal neuroma (fibrous obliteration of the appendix). Inflamm Bowel Dis 2010; 16: 1093-4. [CrossRef] 


\title{
ORIJINAL ÇALIŞMA-ÖZET
}

Turk J Surg 2019; 35 (3): 196-201

\section{Apendektomi örneklerinin rutin histopatolojik incelemesinin hasta yönetimine etkisi: 4012 apendektomi örneği}

\author{
Osama Elfaedy ${ }^{1}$, Mohamed Benkhadoura ${ }^{2}$, Akrem Elshaikhy $^{3}$, Khaled Elgazwi ${ }^{3}$ \\ 1 St. Luke's Hastanesi, Genel Cerrahi Bölümü, Kilkenny, İrlanda \\ 2 Bingazi Üniversitesi Bingazi Tıp Merkezi, Genel Cerrahi Bölümü, Bingazi, Libya \\ ${ }^{3}$ Bingazi Üniversitesi, Al-jala Hastanesi, Genel Cerrahi Bölümü, Bingazi, Libya
}

\section{ÖZET}

Giriş ve Amaç: Akut apandisit tanısı şüphenilen durumlarda apendektomi en yaygın acil abdomen ameliyatlarından birini oluşturmaktadır. Ancak, tüm apendektomi örneklerinin rutin histopatolojik değerlendirilmesi (HPE) son yıllarda tartışılan bir konu olmuştur. Bu çalışmanın amacı, apendektomi örneklerine HPE yapılmasının gerekli olup olmadığını ve HPE'nin detaylı hasta yönetiminde bir etkiye sahip olup olmadığını ortaya koymaktı.

Gereç ve Yöntem: Ocak 2009-Haziran 2017 tarihleri arasında akut apandisit klinik şüphesiyle 4012 ardışık apendektomi örneklerinin histopatolojik raporları iki üniversite hastanesinde retrospektif olarak incelendi.

Bulgular: Toplam 4012 olgu içerisinde, 3530 (\%88)'u, HPE'de akut apandisit ile uyumlu bulgular gösterdi. Perforasyon oranı \%5,8 ve anlamlı derecede erkeklerde $(p<0,001)$ ve $>30$ yaş grubunda daha yüksekti $(p=0,024)$. Negatif apendektomi oranı \%5,6 idi ve kadın hastalarda anlamlı şekilde daha yüksek bulundu $(p<0,001) .256(\% 6,4)$ hastanın HPE'sinde olağandışı bulgulara rastlandı; bunlar sırasıyla kronik apandisit hastaları $(n=207$; $\% 5,2)$, Enterobius vermicularis ( $n=14)$, Schistosoma $(n=8)$, Crohn's hastalığı $(n=1)$, nöroma $(n=10)$, karsinoid tümör $(n=5)$, musinöz kistadenoma $(n=5)$, mukosel $(n=4)$ ve musinöz kistadenokarsinoma $(n=2)$ idi.

Sonuç: Apandiste yapılan hem akut apandisit tanısını doğrular hem de hasta yönetimine etki edebilecek diğer olağandıșı tanıları tespit eder. Olağandışı histopatolojik buğusu olan birkaç hasta anti-helmentik tedavi, kolektomi, gastroenteroloji takibi veya periyodik takip gerektirmektedir. Bu yüzden, tüm appendektomi örneklerine rutin HPE yapılmalıdır.

Anahtar Kelimeler: Apendektomi, apandisit, histopatolojik değerlendirme

DOi: $10.5578 /$ turkjsurg. 4253 